\title{
Effect of Die Bearing Parameters on Corrosion Response of Extruded Al-Zn-Mg Alloy
}

\author{
Injor Oryina Mbaadega ${ }^{1}$, Adewuyi Benjamin Omotayo ${ }^{1}$, Gundu David Terfa ${ }^{2}$ \\ ${ }^{1}$ Department of Metallurgical and Materials Engineering, Federal University of Technology, Akure, Nigeria \\ ${ }^{2}$ Department of Mechanical Engineering, University of Agriculture, Makurdi, Nigeria
}

\author{
Email address: \\ dtergundu@yahoo.com (D. T. Gundu)
}

\section{To cite this article:}

Injor Oryina Mbaadega, Adewuyi Benjamin Omotayo, Gundu David Terfa. Effect of Die Bearing Parameters on Corrosion Response of Extruded Al-Zn-Mg Alloy. International Journal of Materials Science and Applications. Vol. 4, No. 3, 2015, pp. $209-212$.

doi: $10.11648 /$ j.ijmsa.20150403.19

\begin{abstract}
In this paper, the effect of die bearing parameters (die bearing length and die reduction ratio) on corrosion response of extruded Al-Zn-Mg alloy was investigated. The alloy was target material for production of automobile bumper beams. Medium carbon steel dies with entry angles of 750, 900, 1050, 1200, 1500 and reduction ratios of $0.21,0.40,0.48$ and 0.62 were used to extrude the alloy at temperature of $5000 \mathrm{C}$. The extruded samples were subjected to electrochemical corrosion using Tafel polarization technique. The potential dynamic polarization curves indicated improvement in the corrosion resistance of the extruded alloy, and the corrosion rate under extruded condition increased with increase in both die angle and reduction ratio. It was concluded that the $\mathrm{Al}-\mathrm{Zn}-\mathrm{Mg}$ alloy is suitable for the target application.
\end{abstract}

Keywords: Extrusion, Al-Zn-Mg Alloy, Die Entrant Angle, Die Reduction Ratio, Potential Dynamic Polarization, Corrosion Rate

\section{Introduction}

Corrosion, an inevitable problem faced in almost all industries, can be considered as one of the worst technical calamity of our time. Besides direct loss in dollars, corrosion is a serious problem because it definitely contributes to the depletion of our natural resources, and corrosion studies have also become important due to increasing awareness of the need to conserve the world's metal resources [1]. Corrosion studies of aluminium and alloys have continued to receive considerable attention by researchers because of their technological importance and industrial applications. Due to their attractive properties, such as low density, high strength, ductility, toughness and resistance to fatigue, $\mathrm{Al}-\mathrm{Zn}-\mathrm{Mg}-\mathrm{Cu}$ alloys have been widely used as structural materials. However, $\mathrm{Al}-\mathrm{Zn}-\mathrm{Mg}-\mathrm{Cu}$ alloys have low corrosion resistance and are susceptible to local corrosion, like pitting, intergranular corrosion (IGC), exfoliation corrosion (EXCO) and stress corrosion cracking (SCC) [2]. A major corrosion issue with aluminium is the localized breakdown of the passive film, which leads to the induction and growing of corrosion cavities in chloride containing environments. New heat treatments of the $\mathrm{Al}-\mathrm{Zn}-\mathrm{Mg}-\mathrm{Cu}$ alloys can improve the corrosion resistance, optimum mechanical properties which change the microstructure of the alloy in order to obtain the desired properties [3]. For applications involving welding fabrication, Al-Zn-Mg alloys have the advantage in their ability to age-harden at room temperature to obtain very high weld strength and efficiency [4]. Whereas mechanical properties may be improved through increase of alloying element concentrations followed by precipitation, such procedures frequently increase susceptibility of the alloy to localized corrosion. This is usually due to an increased volume fraction of second phase precipitates. However, traditional metallurgical approaches are restricted through the limited solubility of many of the principal alloying elements, including $\mathrm{Zr}$, Sc, Ti, Ni, etc, in the aluminium matrix. Several studies have reported that this limitation could be overcome with the use of technologies which provide much higher solubility, refined microstructures, reduced segregation and eliminate coarsely precipitated intermetallic. Such processes vary from the widely used chromate treatment to rare earth metal salts dip treatment [5 - 8]. In recent years, much research has been carried out to search for more environmentally acceptable processes instead of chromate treatment in surface modification process of magnesium alloys. Microstructure improvement can be improved by 
powder compacting and mechanical forming processes to obtain improved microstructures with grain size up to 1-1.5 1 $\mathrm{m}$ [7]. Other studies [10 - 13] have also shown that extrusion flow conditions, owing to varying die bearing parameters, are affected by the die geometry, and this also affects the resulting microstructure and corrosion resistance of the extruded metal. Optimization of die bearing parameters is therefore very important as it directly affects among other parameters surface finish and corrosion resistance of the extruded products.

In this paper the effects extrusion die bearing parameters on $\mathrm{Al}-\mathrm{Zn}-\mathrm{Mg}$ alloy in stagnant naturally aerated neutral $\mathrm{NaCl}$ solution was evaluated. The alloy was target material for production of automobile bumper beams. The corrosion rate was determined using conventional electrochemical Tafel potential dynamic polarization technique [13]. Electrochemical measurements were carried out using AutoLab potentiostat at room temperature, and the experimental impedance data were fitted to theoretical values according to equivalent circuit models, were recorded and used to generate the potential dynamic current-potential curves [11].

\section{Experimental Methodology}

\subsection{Materials}

Square billets of $25.4 \mathrm{~mm}$ diameter and $25.4 \mathrm{~mm}$ length were cut from cast and machined samples of Al-Zn-Mg alloy with elemental composition as obtained by Atomic Absorption Spectrometry (AAS) given in Table1.

Table 1. AAS Composition of Al-Zn-Mg alloy.

\begin{tabular}{lllll}
\hline Element & Al & Zn & Mg & Others \\
\hline$\%$ & 80.1173 & 11.0178 & 6.0746 & 2.7903 \\
\hline
\end{tabular}

Extrusion dies with entry angles of $750,900,1050,1200$, 1500 , and die reduction ratios of $0.21,0.40,0.48,0.62$ were used.

\subsection{Extrusion Procedure}

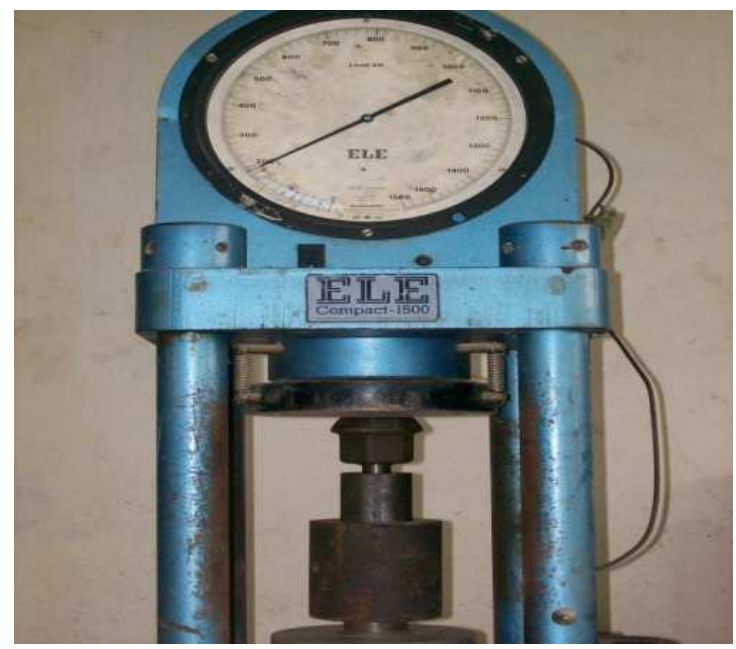

Figure 1. Extrusion setup.
The aluminium alloy was melted and cast in sand molds to $\varnothing 26 \mathrm{~mm}$. Extrusion billets were machined to $\varnothing 25.4 \mathrm{~mm} \mathrm{x}$ $25.4 \mathrm{~mm}$. The extrusion rig was used for the extrusions in [10], and extrusion billets were direct extruded on the manual ELE Compact-1500 hydraulic compression testing machine as shown on Figure 1.

\subsection{Electrochemical and Tafel Polarization Measurements}

Cylindrical test samples of the extruded Al-Zn-Mg alloy were sealed with acrylic resin material in such a way that the area exposed to the medium was $1.0 \mathrm{~cm} 2$, and were polished and then dried to avoid moisture before subjected to corrosion. Electrochemical measurements were carried out using AutoLab potentiostat at room temperature. The electrochemical cell was a conventional three electrode compartment having glass cell with a platinum counter electrode and a saturated calomel electrode (SCE) as reference. The working electrode was made up of $\mathrm{Al}-\mathrm{Zn}-\mathrm{Mg}$ alloy. All the values of potential difference were measured with reference to the SCE. The finely polished specimens were exposed to corrosion medium of $0.1 \mathrm{M}$ concentration of sodium chloride $(\mathrm{NaCl})$ at room temperature. Before measurements, specimens were held in the test solution for 1 $\mathrm{h}$ to establish a steady open circuit corrosion potential, $\mathrm{E}_{\text {corr }}$. The potential dynamic current-potential curves were recorded by polarizing the specimens to $-250 \mathrm{mV}$ (cathode) and +250 $\mathrm{mV}$ (anode) with respect to open circuit potential (OCP) at a scan rate of $0.01 \mathrm{~V} / \mathrm{s}$.

\subsection{Micrographs}

Samples for microstructural analysis were ground successively to 1200 microns using emery paper and polished with $\mathrm{SiC}$ powder to produce mirror surfaces, and then etched in sodium hydroxide $(\mathrm{NaOH})$ solution for 10 seconds. Micrographs were obtained using AX optical metallurgical and CMOS digital microscopes at X100 magnification.

\section{Results and Discussion}

\subsection{Microstructure Response}

Figures 2 and 3 show that the microstructures consist mainly of intermetallic particles enriched with zinc and magnesium [3, 5, 9] which are responsible for initiating pitting corrosion. The width of the enrichment zone correlates with microstructure refinement, and the backscattered electron images reveal a relatively dark matrix within areas of intense precipitation of the $\mathrm{Zn}-\mathrm{Mg}$ base phases compared with other areas. From Figure 2, the structures corresponding to the die angle of 90 o shows a nearly pore-free matrix with many fine precipitates indicating better flow conditions and properties than would be obtained with as cast and other die angles [7, 10]. The micrographs of Figure 3 show grain refinement as die reduction ratio is increased owing to large deformations which breakdown large crystals and any discontinuities as suggested by the findings of earlier studies $[7,8,11,12]$. 


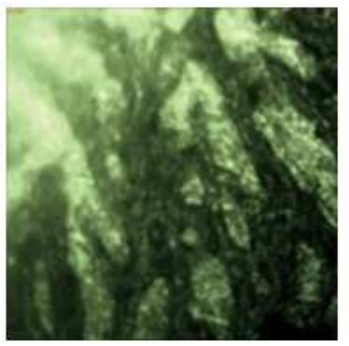

(As cast)

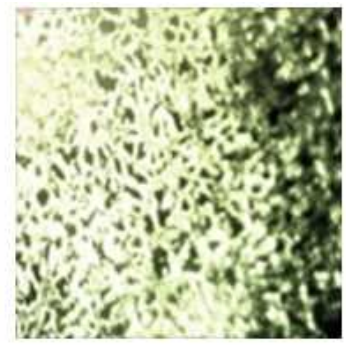

$\left(75^{\circ}\right)$

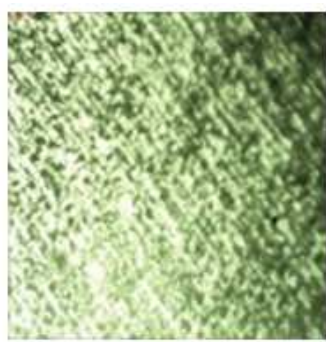

$\left(90^{\circ}\right)$

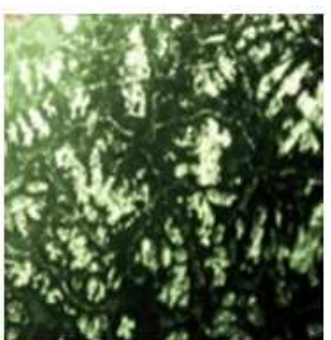

$\left(105^{\circ}\right)$

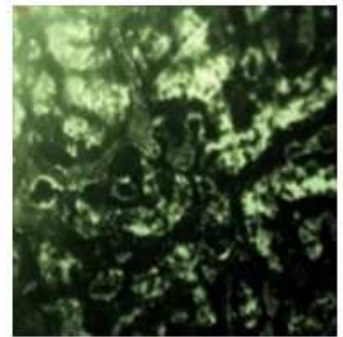

$\left(120^{\circ}\right)$

Figure 2. Micrographs of extruded samples at various die angle.

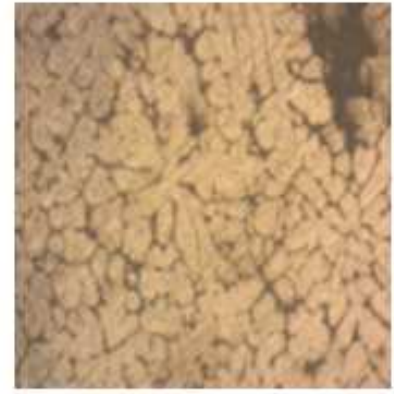

$(\mathrm{R}=0.21)$

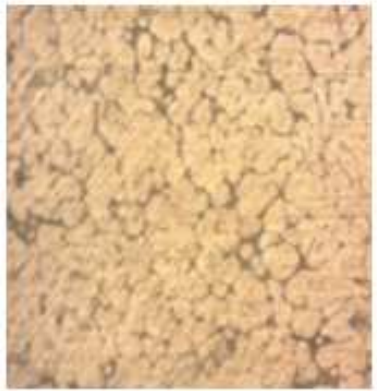

$(\mathrm{R}=0.40)$

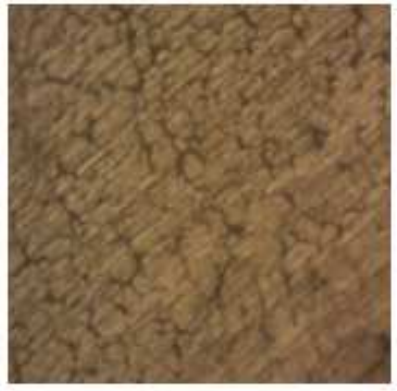

$(\mathrm{R}=0.48)$

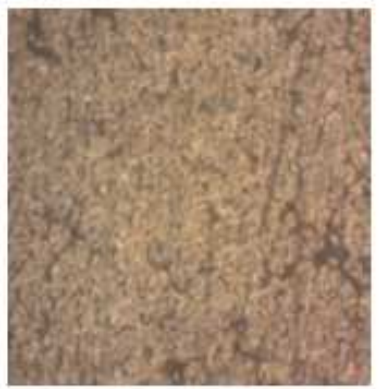

$(\mathrm{R}=0.62)$

Figure 3. Micrographs of extruded samples at various reduction ratio (R).

\subsection{Corrosion Response}

Figure 4 and 5 shows that corrosion rate was affected as die geometry is changed; following extrusion, the corrosion rate reduced drastically from $0.06561 \mathrm{~mm} / \mathrm{yr}$. for the as cast samples. In Figure 4, the corrosion rate is lower with the die angle of 900 compared to the other die angles. This is attributed to better flow condition at lower extrusion pressure, with reduced discontinuities in the oxide film, thereby reducing the number of sites where corrosion can be initiated $[7,10,15]$. Similarly in Figure 5, increasing die ratio reduced corrosion rate. These trends are consistent with the microstructure response of the $\mathrm{Al}-\mathrm{Zn}-\mathrm{Mg}$ alloy presented above [15].

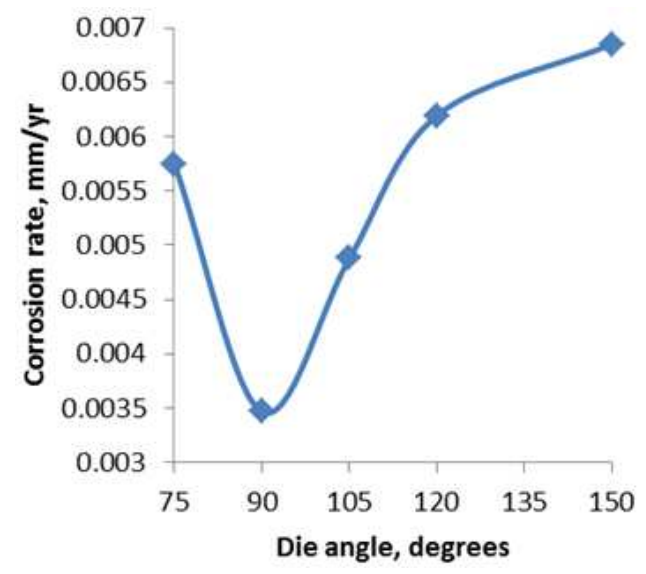

Figure 4. Plot of corrosion rate against die angle.

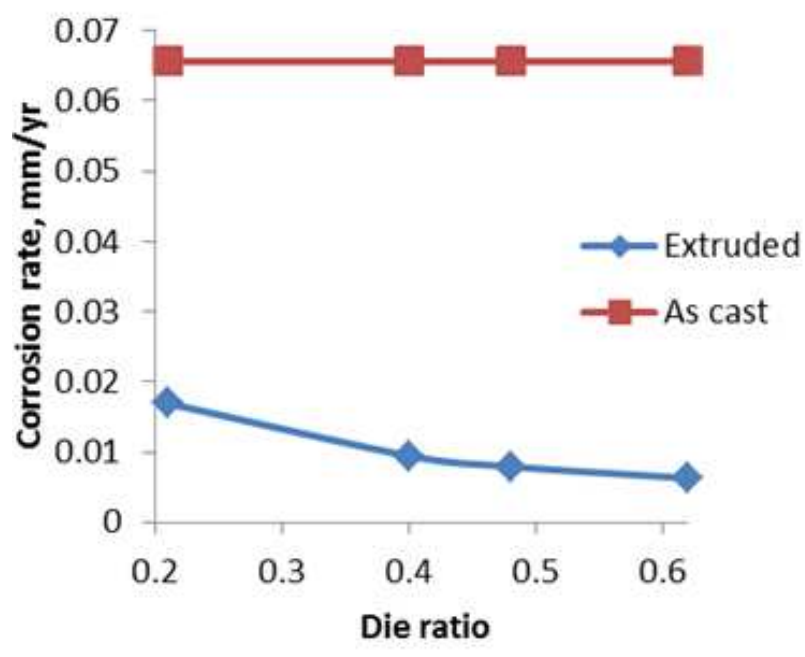

Figure 5. Plot of corrosion rate against die ratio.

Figures 6 and 7 represent the potential dynamic polarization curves for different die angles and reduction ratios at $25 \mathrm{oC}$ respectively. From these figures, the corrosion potential is shifted in the positive direction as the die angle and reduction ratio are increased. The positive shift in the corrosion potential $\mathrm{E}_{\text {corr }}$ indicate that the anodic process is much more affected than the cathodic process [13]. Tafel slopes remained almost unchanged indicating that die angle and reduction ratios do not change the mechanism of the corrosion process. 


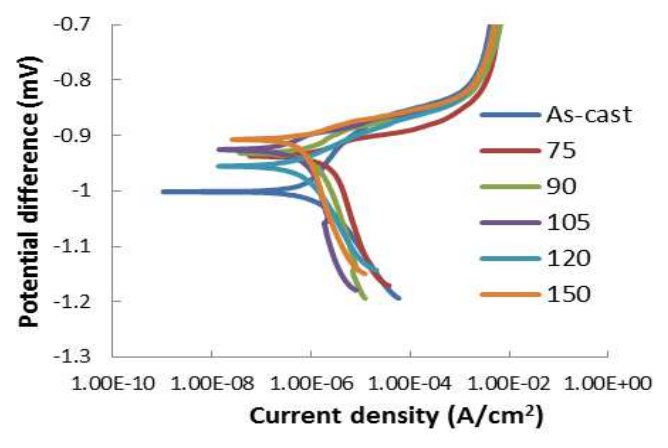

Figure 6. Polarization curves for various die angles.

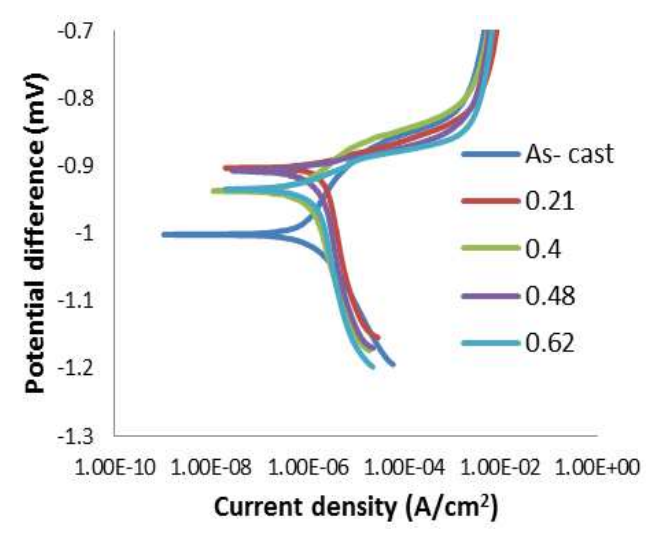

Figure 7. Polarization curves for die reduction ratios.

\section{Conclusion}

The study has shown that corrosion resistance of Al-Zn$\mathrm{Mg}$ alloy is affected by die bearing parameters (die entrant angle and die reduction ratio). However, while there is improvement in microstructure and corrosion resistance of the alloy with extrusion, these are dependent on the die geometry and the resulting flow condition. Corrosion rate is considerably reduced with the die angle of 900, and lower corrosion rates are obtainable with higher die reduction ratios. The potential dynamic curves suggest that the anodic process is much more affected than the cathodic process, and that die angle and reduction ratio do not change the mechanism of the corrosion process. Given the corrosion response to extrusion processing parameters, it was concluded that the $\mathrm{Al}-\mathrm{Zn}-\mathrm{Mg}$ alloy is suitable for the target application.

\section{References}

[1] Stansbury E.E and Buchanan R.A. (2000). Fundamentals of Electrochemical Corrosion ASM. International Materials Park, USA.
[2] Conde, A., Fernandez, B. and De Damborenea, J. (1998): Corrosion Science, 40: 91.

[3] Naeem, H. T., Mohammed, K. S., Ahmad, K. R. and Rahmat, A. (2014): Corrosion Behaviour of The Al-Zn-Mg-Cu Alloys With Nickel Additions. Digest Journal of Nanomaterials and Biostructures. 9(4): 1309 - 1315.

[4] AFSA Corrosion Pocket Guide (2011): Corrosion Resistance of Aluminium and Protective Measures where Appropriate. 1st Edition, Aluminium Federation of South Africa, 36p.

[5] Nadia, H. H. (2011): Corrosion inhibition and adsorption behavior of methionine on $\mathrm{Mg}$ - $\mathrm{Al}-\mathrm{Zn}$ alloy. Journal of Chemical Engineering and Materials Science Vol. 2(2): 28-38.

[6] Badawy, W. A., Nady, H. and Abd El-Hafez, G. M. (2014): Corrosion Inhibition of Mg-Al-Zn Alloy in Neutral Chloride Solutions by N-Acetyl-Cysteine as Eco-Friendly Material. International Journal of Engineering and Innovative Technology (IJEIT), 4(3): 125-132.

[7] Sameljuk, A.V., Neikov, O.D., Krajnikov, A.V., Milman, Yu.V. and Thompson, G.E. (2004): Corrosion behaviour of powder metallurgical and cast $\mathrm{Al}-\mathrm{Zn}-\mathrm{Mg}$ base alloys. Corrosion Science. 46: 147-158.

[8] Rudd, A.L., Breslin, C.B. and Mansfeld, F. (2000): The corrosion protection afforded by rare earth conversion coatings applied to magnesium Corrosion Science, 42: 257.

[9] Yfantis, A., Paloumpa, I., Schmei, D, and Yfantis, D. (2002). Novel corrosion resistant films for $\mathrm{Mg}$ alloys. Surface and Coatings Technology, 151-152: 400-404.

[10] Gundu, T., Tuleun, L. and Injor, O. (2014): Effect of Pocket Die Bearing Geometry on Direct Cold Extrusion Process Responses. American Journal of Mechanical Engineering. 2-33: 65-69.

[11] Flitta, I. and Sheppard, T. (2003): Nature of friction in extrusion process and its effect on material flow. Materials Science and Technology 19: 837-846.

[12] Piwnik, J. and Mogielnicki, K. (2010): The friction influence of stress in micro extrusion. Archives of Foundry Engineering 10(1): 451-454.

[13] El- Sayed (1997): Phenothiazine as inhibitor of the corrosion of cadmium in acidic solutions. J. Appl. Electrochem., 27: 193-200.

[14] Alvarez, J. O., Gonzalez, C., Aramburu, G., Herrera, R., Juarez - Islas, J.A. (2005): The effect of adding different $\mathrm{Mg}$ contents to an $\mathrm{Al}-12 \mathrm{wt} . \% \mathrm{Zn}$ master alloy. Materials Science and Engineering A402: 320 - 324.

[15] Pardo A., Merino M.C., Merino S., Lopez M.D., Viejo F. and Carboneras M. (2003): Influence of reinforcement grade and matrix composition on corrosion resistance of cast aluminium matrix composites (A3xx.x/SiCp) in a humid environment. Mater. Corros., 54: 311-317. 